\title{
PELATIHAN EFIKASI DIRI UNTUK MENINGKATKAN EFIKASI DIRI TERHADAP KEMAMPUAN BERWIRAUSAHA ANAK DOWN SYINDORME PADA ORANGTUA
}

\section{SELF-EFFICACY TRAINING TO IMPROVE PARENTS' SELF-EFFICACY TOWARD THE ENTREPRENEURSHIP ABILITY OF THEIR DOWN SYNDROME CHILDREN}

\author{
Sowanya Ardi Prahara ${ }^{1}$, Kondang Budiyani ${ }^{2}$ \\ ${ }^{12}$ Universitas Mercu Buana Yogyakarta \\ 1'sowanya_hara@yahoo.com
}

\begin{abstract}
Abstrak
Penelitian ini bertujuan untuk memperoleh bukti empiris apakah pelatihan efikasi diri mampu meningkatkan efikasi terhadap kemampuan berwirausaha anak down syndrome pada diri orangtua. Hipotesis yang diajukan adalah ada perbedaan efikasi diri orangtua terhadap kemampuan berwirausaha anak down syndrome sebelum dan sesudah pelatihan pada kelompok eksperimen. Subjek penelitian sebanyak 6 orangtua yang memiliki anak down syndrome yang mendapatkan skor rendah dari Skala Efikasi Diri terhadap kemampuan berwirausaha anak down syndrome. Design eksperimen yang digunakan adalah one group pretest-postest design. Hasil analisis data menggunakan teknik analisis data Wilcoxon matched pairs sigend-ranks test menunjukkan nilai $\mathrm{Z}$ yang didapat sebesar -2.207 dengan $\mathrm{p}=0.0135(\mathrm{p}=<0.05)$. Hasil tersebut menunjukkan adanya perbedaan tingkat efikasi diri terhadap kemampuan berwirausaha anak down syndrome pada orangtua yang signifikan antara sebelum dan setelah diberikan pelatihan efikasi diri.
\end{abstract}

Kata Kunci: pelatihan efikasi diri, efikasi diri, down syndrome, wirausaha

\begin{abstract}
This research aims to obtain empirical evidence whether the self-efficacy training can improve parents' efficacy toward the entrepreneurship ability of their Down syndrome children. The hypothesis proposed in this research is that there are differences in parents' self-efficacy toward their Down syndrome children's entrepreneurship ability before and after training in the experimental group. Six participants got low scores of Self-Efficacy Scale toward their Down syndrome children's entrepreneurship ability. This experimental research used one group pretest-postest design. The data analysis using Wilcoxon matched pairs sigend-ranks test showed that the gained Z score is -2.207 with $p=0.0135(p=<0.05)$. The result showed that there is a significant difference in parents' selfefficacy level toward their Down syndrome children's entrepreneurship ability before and after the self-efficacy training.
\end{abstract}

Keyword: Self-efficay training, self-efficacy, down syndrome, entrepreneurship

\section{PENDAHULUAN}

Perkembangan teknologi di bidang kesehatan pada jaman moderen ini berkembang sangat pesat. Sehingga penanganan terhadap anak-anak dengan Down syndrome menjadi lebih baik. Hal ini terlihat pada hasil penelitian yang dilakukan oleh Sadock, dkk. (1999) yang menunjukkan usia harapan hidup anak dengan down syndorme kira-kira 12 tahun, 
namun sekarang dengan adanya kemajuan antibiotik, sedikit pasien muda menderita infeksi, dan banyak dari penderita yang dapat hidup hingga lebih dari 40 tahun. Senada diungkapkan oleh Buckley (2000) bahwa usia harapan hidup anak Down syndrome antara usia 40 hingga 50 tahun, bahkan beberapa dapat hidup hingga usia 60 hingga 70 tahun. Hal ini menjadi penting bahwa anak-anak tersebut harus mendapatkan keuntungan dari kesempatan mendapatkan pendidikan yang dapat membuat lebih berguna dan hidup sebagai orang dewasa yang semi independent di dalam masyarakat. Dijelaskan lebih lanjut bahwa orang dewasa dengan Down syndrome mampu menjalani hidup biasa di dalam masyarakat, seperti berbelanja, bekerja, pergi ke kampus, dan ke klub dengan bantuan yang minimal. Sisa lainnya (15\%) membutuhkan lebih banyak bantuan dalam kehidupannya sehari-hari. Selain itu, orang dengan down syndrom yang sudah dewasa memiliki kebutuhan-kebutuhan seperti orang dewasa pada umumnya yaitu memiliki kebutuhan sosial, emosi dan kebutuhan berprestasi, kebutuhan kebebasan, hidup mandiri, kebutuhan berteman, memiliki pasangan hidup dan memiliki kebutuhan berperan menjadi orang yang berperan dalam masyarakat (Buckley \& Bird, 2000). Senada dengan penuturan dari Ketua POTADS Jogja Ibu Kiki Ekasasi yang menyatakan bahwa banyak orang dewasa dengan Down syndrom di negara maju telah memperoleh pekerjaan, bias hidup mandiri, dan menemukan pasangan untuk menikah. Namun, di negara berkembang, anak dan orang dewasa dengan Down syndrom masih berjuang untuk mendapatkan hak-hak dalam masyarakat dan mendapatkan pendidikan, mendapatkan layanan kesehatan dan pendidikan dasar.

Berdasarkan uraian data di atas, maka anak dengan Down syndrome sebetulnya masih dapat dididik dan dikembangkan menjadi anak yang lebih mandiri pada saat dewasanya. Namun, dalam hal ini menuntut orangtua sebagai agen terdekat untuk mampu memberikan dukungan dan bantuan tersebut. Menurut Buckley (2000), orangtua yang memberikan dukungan berupa kebutuhan-kebutuhan pada anak dengan Down syndrome di rumah, akan membuat anak dengan Down syndrome lebih independen dalam kehidupannya sehari-hari, pekerjaan dan segi-segi kehidupan pada umumnya di masa dewasanya. Salah satu hal yang dapat dilakukan keluarga adalah melatih orang dengan Down syndrome agar dapat berwirausaha karena orang dengan Down syndrome tidak mudah mendapatkan pekerjaan.

Kemampuan orangtua dalam memberikan dukungan ini tidak dapat dilepaskan dari konsep self efficacy (efikasi diri). Efikasi diri merupakan keyakinan seseorang terhadap kemampuan atau kompetisinya untuk melakukan sebuah tugas, mencapai tujuan, atau mengatasi hambatan tertentu (Bandura, 2009). Pada orangtua yang memiliki anak down syndrom, efikasi diri menjadi penting karena keyakinan atas kemampuan yang dimiliki 
dalam menyelesaikan masalah dan mengatasi hambatan menjadi sangat diperlukan. Selanjutnya Bandura (1997) menyebutkan bahwa aspek-aspek efikasi diri terdiri dari magnitude, yaitu berkaitan dengan tingkat kesulitan tugas di mana individu merasa mampu melakukannya. Yang kedua yaitu strength, mengacu pada derajat kemampuan individu terhadap keyakinan akan harapan yang telah dibuatnya. Dan yang ketiga adalah generality, yaitu berkaitan dengan tingkat kekuatan atau kemantapan seseorang terhadap keyakinannya.

Bandura (Bernstein, Nietzel \& Millich, 1998) mengemukakan bahwa efikasi diri sangat berpengaruh pada bagaimana seseorang akan berperilaku. Semakin tinggi efikasi diri maka akan semakin baik performennya/prestasinya. Orang yang efikasi dirinya rendah kemungkinan akan merasa apatis. Sebaliknya orang yang efikasi diri tinggi akan optimis. Berdasarkan hal ini maka peneliti berasumsi bahwa salah satu yang perlu diubah terkait mempersiapkan orang dengan down syndrom untuk hidup mandiri adalah efikasi diri yang rendah dari orangtua terhadap kemampuan wirausaha anak dengan Down syndrom. Hal ini dikuatkan dengan hasil wawancara dengan 4 orangtua yang memiliki anak Down syndrome pada tanggal 26 Oktober 2016 di SLB Negeri Yogyakarta menunjukkan bahwa orangtua tidak yakin terhadap kemampuan anaknya yang down syndrom. Orangtua tidak yakin karena selama ini belum banyak tahu bahwa orang dengan Down syndrome berhasil dalam berwirausaha.

Bandura (1997) mengemukakan sumber-sumber yang mempengaruhi pembentukan efikasi diri meliputi : (1) Mastery experience (pengalaman keberhasilan) merupakan hasil yang dicapai individu melalui pengalaman keberhasilan sebelumnya, sehingga berhubungan langsung dengan pengalaman pribadi yang akan meningkatkan efikasi diri seseorang; (2) Vicarious experience atau modelling (meniru pengalaman keberhasilan orang lain) merupakan peningkatkan efikasi diri dengan cara melihat apa yang telah dicapai orang lain karena pencapaian orang lain dapat menjadi tolok ukur terhadap kemampuan yang dimiliki; (3) Social persuasion (persuasi verbal) merupakan peningkatan efikasi diri dari orang lain yaitu orang lain mendorong dan meyakinkan seseorang untuk melakukan tugas sehingga orang tersebut percaya bahwa ia memiliki kemampuan melakukan tugas; (4) Physiological state and emotional arousal (keadaan fisiologisdan psikologis) merupakan usaha peningkatan efikasi diri dengan cara memberikan kondisi agar seseorang tidak mengalami kecemasan.

Sebelum seseorang melakukan atau memunculkan perilaku tertentu dibutuhkan aspek kepercayaan diri akan kemampuan yang dimiliki, atau disebut sebagai efikasi diri. Efikasi diri merupakan kepercayaan diri yang dimiliki individu. Sehingga dengan memiliki efikasi 
diri yang tinggi, maka seseorang akan mampu menghasilkan sesuatu dengan lebih baik. Keyakinan dalam diri menentukan bagaimana orang merasa, berfikir memotivasi diri dan berperilaku. Begitu juga efikasi diri orangtua terhadap kemampuan berwirausaha anak Down syndrome. Diharapkan orangtua tersebut mampu memperlakukan anak Down syndrome dengan lebih baik.

Vicarious experience merupakan salah satu cara yang efektif dalam menciptkan rasa yang kuat akan keberhasilan dengan melihat akan keberhasilan orang lain (Bandura, 2009). Lebih lanjut dijelaskan bahwa dengan melihat keberhasilan pengalaman individu dalam menyelesaikan suatu perosalan akan memperkokoh keyakinan atas kemampuan yang dimiliki, sebaliknya apabila terjadi kegagalan maka akan menjadikan seseorang ragu terhadap potensi yang dimiliki, terutama saat efikasi diri belum menetap dalam dirinya. Keberhasilan dari model akan membangun kepercayaan yang kuat dalam keberhasilan pribadi seseorang. Akan tetapi kegagalan model akan merusak, terutama jika kegagalan terjadi sebelum keberhasilan benar-benar hadir.

Dalam hal ini guna meningkatkan efikasi diri orangtua terhadap kemampuan kewirausahaan anak Down syndrome salah satunya memberikan pelatihan efikasi diri dengan menunjukkan video keberhasilan anak-anak Down syndrome dan cerita kesuksesan orangtua dalam mendampingi anak Down syndrome berwirausaha. Menurut Ancok (2002) pelatihan adalah suatu metode untuk membiasakan diri, karena pelatihan menggunakan simulasisimulasi kehidupan sehari-hari, adanya pembelajaran berdasarkan pengalaman dan menggunakan permainan-permainan yang menyenangkan. Metode pelatihan yang diberikan berupa pemutaran video dan sharing dari orangtua yang berisikan cerita-cerita keberhasilan anak-anak Down syndrom dalam menjalankan usaha, diberikan pengetahuan dan tips bagaimana mendampingi anak Down syndrome berwirausaha, serta diberikan pengalaman langsung dalam mendampingi anak dalam berwirausaha dan diberikan penguatan berupa perusasi verbal. Dengan diberikannya pelatihan efikasi diri diharapkan para orangtua memperoleh keyakinan terhadap kemampuannya dalam melakukan sebuah tugas, mencapai tujuan, serta dalam mengatasi hambatan-hambatan dalam mendidik anak Down syndrome.

Hipotesis yang diajukan adalah ada perbedaan efikasi diri terhadap kemampuan beriwausaha anak Down syndrome pada orangtua sebelum dan sesudah tritmen.

\section{METODE}

Subjek dalam penelitian ini adalah orangtua dengan anak Down syndrome yang memiliki efikasi diri yang rendah $(49,34,40,42,38$, dan 46) terhadap kemampuan 
berwirausaha pada anak-anaknya yang menderita Down syndrome. Subjek penelitian berjumlah 6 orang yang dijadikan subjek penelitian dan kesemuanya dimasukkan ke dalam kelompok eksperimen.

Alat pengumpul data yang digunakan dalam penelitian ini adalah Skala Efikasi Diri ini mengacu pada aspek-aspek efikasi diri yang dikemukakan oleh Bandura (1997) bahwa terdapat tiga hal yang dapat digunakan untukmembentuk efikasi diri, yaitu level, generality dan strength.

Skala Efikasi Diri berisi pernyataan yang terdiri dari 15 aitem. Masing-masing pernyataan terdiri dari 4 alternatif jawaban yaitu sangat sesuai (SS), sesuai (S), tidak sesuai (TS) dan sangat tidak sesuai (STS). Pemberian penilaian adalah sebagai berikut sangat sesuai (SS) dinilai 4, sesuai (S) dinilai 3, tidak sesuai (TS) dinilai 2 dan sangat tidak sesuai (STS) dinilai 1. Semakin tinggi skor menunjukkan semakin tinggi skor efikasi diri, sebaliknya semakin rendah skor menunjukkan semakin rendah skor efikasi diri. Hasil uji coba menunjukkan koefisien daya beda aitem bergerak 0.448-0.756. Jumlah aitem keseluruhan adalah 15 aitem sehingga tidak ada aitem yang gugur semua aitem terpakai. Adapaun reliabilitas skala sebesar 0.916 .

Pelatihan efikasi diri disusun berdasarkan teori Bandura (1997), yaitu vicarious experience, mastery experience, physiological state, dan verbal persuation. Metode yang digunakan adalah dengan ceramah, penayangan film, diskusi dan permainan. Sebelum digunakan, modul pelatihan efikasi diri diberikan profesional judgement. Adapun prosesnya, modul pelatihan diberikan pada seorang ahli untuk di cek konten materinya, setelah itu modul diuji cobakan. Berdasarkan hasil professional judgement, peneliti diminta untuk sedikit merevisi mengenai waktu yang bias lebih dipersingkat.

Rancangan eksperimen yang digunakan adalah one group pretest-posttest design yaitu kelompok eksperimen dibentuk dengan prosedur random (Azwar, 1999).

\begin{tabular}{cc}
\hline $\mathrm{R}$ & $\mathrm{KE} 01 \times 02$ \\
\hline Gb. 1 Rancangan eksperimen
\end{tabular}

Keterangan:

$\mathrm{R}$ : Random asigment

O1 : Pengukuran tingkat efikasi diri (pretest)

$\mathrm{O} 2$ : Pengukuran tingkat efikasi diri (posttest)

$\mathrm{X}$ : Perlakuan yaitu Pelatihan efikasi diri orangtua 
Analisi data dilakukan dengan menggunakan analisis non parametrik paired sample test dengan uji Wilcoxon. Trihendradi (2009) mengemukakan bahwa paired sample test merupakan analisis yang melibatkan dua pengukuran pada subjek yang sama terhadap suatu pengaruh atau perlakuan tertentu.

\section{HASIL DAN PEMBAHASAN}

Tabel 1. Perbedaan Pretest dan Posttest Kelompok Eksperimen

\begin{tabular}{llll}
\hline $\begin{array}{l}\text { Alat } \\
\text { Ukur }\end{array}$ & $\begin{array}{l}\text { Nilai } \\
\mathbf{Z}\end{array}$ & $\mathbf{P}$ & Kesimpulan \\
\hline Skala & - & 0,027 & Ada \\
Efikasi & 2.207 & $(<0,05)$ & perbedaan \\
Diri & & & \\
\hline
\end{tabular}

Berdasarkan hasil uji analisis Wilcoxon matched pairs signed-ranks test maka ditemukan bahwa nilai z yang didapat sebesar -2.207 dengan $\mathrm{p}=0.027(\mathrm{p}<0.05)$. Berarti ada perbedaan yang signifikan antara tingkat efikasi diri terhadap kemampuan kewirausahaan anak Down syndrome sebelum (pretest) dan sesudah (posttest) diberikan pelatihan efikasi diri. Skor efikasi diri subjek sebelum dan sesudah diberikan pelatihan efikasi diri lebih rendah $($ Mean $=41,5)$ dibandingkan dengan skor efikasi diri subjek setelah diberikan pelatihan efikasi diri $($ Mean $=54,67)$.

Hasil penelitian ini menguatkan penelitian Helmystianti (2017) yang berjudul pengaruh pelatihan strategi peningkatan efikasi diri para guru untuk meningkatkan efikasi diri kemampuan matematika siswa sekolah dasar menunjukkan terjadinya perubahan yang signifikan antara efikasi diri kemampuan matematika siswa sekolah dasar sebelum dan setelah diberikan pelatihan strategi peningkatan efikasi diri. Pelatihan yang dilakukan ini menunjukkan adanya peningkatan efikasi diri kemampuan matematika siswa sekolah dasar setelah diberikan pelatihan strategi peningkatan efikasi diri dengan nilai $\mathrm{t}=-3.164(\mathrm{p}<0.01)$ yang berarti hipotesis dalam penelitiannya diterima yaitu pelatihan strategi peningkatan efikasi diri para guru mampu meningkatkan efikasi diri kemampuan matematika siswa sekolah dasar.

Berdasarkan analisis terhadap ujia hipotesis, diketahui bahwa terdapat perbedaan yang signifikan antara tingkat efikasi diri terhadap kemampuan kewirausahaan anak Down syndrome sebelum (pretest) dan sesudah (posttest) diberikan pelatihan efikasi diri. Melalui analisis Wilcoxson signed rank test didapatkan nilai z -2.207 dengan taraf signifikansi $\mathrm{p}=$ 0.027 ( $\mathrm{p}<0.05$ ). Nilai tersebut bermakna bahwa pemberian pelatihan efikasi diri berpengaruh secara signifikan untuk meningkatkan efikasi diri terhadap kemampuan 
berwirausaha anak Down syndorme pada orangtua. Skor efikasi diri subjek sebelum dan sesudah diberikan pelatihan efikasi diri lebih rendah $($ Mean $=41,5)$ dibandingkan dengan skor efikasi diri subjek setelah diberikan pelatihan efikasi diri $($ Mean $=54,67)$. Hal tersebut menunjukkan bahwa hipotesis yang menyatakan tingkat efikasi diri terhadap kemampuan berwirausaha anak Down syndrome pada orangtua setelah diberikan pelatihan efikasi diri lebih tinggi dibandingkan dengan tingkat efikasi diri subjek sebelum diberikan pelatihan efikasi diri diterima.

Tingkat efikasi diri terhadap kemampuan kewirausahaan anak Down syndrome sebelum (pretest) lebih rendah dibandingkan dengan tingkat efikasi diri subjek setelah diberi perlakuan. Adanya kenaikan skor efikasi diri tersebut dapat dilihat secara lebih rinci pada tabel 6. Melalui tabel tersebut dapat diketahui bahwa keenam subjek penelitian mengalami peningkatan skor efikasi diri. Sebelum diberikan perlakukan pelatihan efikasi diri, efikasi diri terhadap kemampuan berwirausaha anak Down syndrome pada orangtua, 5 orang berada pada kategori rendah dan 1 orang berada pada kategori sedang, lalu setelah diberikan perlakuan pelatihan efikasi diri, maka efikasi diri subjek mengalami kenaikan sehingga 5 orang berada pada kategorisasi sedang dan 1 orang berada pada kategorisasi rendah.

Hasil penelitian ini menguatkan penelitian Helmystianti (2017) yang berjudul pengaruh pelatihan strategi peningkatan efikasi diri para guru untuk meningkatkan efikasi diri kemampuan matematika siswa sekolah dasar menunjukkan terjadinya perubahan yang signifikan antara efikasi diri kemampuan matematika siswa sekolah dasar sebelum dan setelah diberikan pelatihan strategi peningkatan efikasi diri. Pelatihan yang dilakukan ini menunjukkan adanya peningkatan efikasi diri kemampuan matematika siswa sekolah dasar setelah diberikan pelatihan strategi peningkatan efikasi diri dengan nilai $\mathrm{t}=-3.164(\mathrm{p}<0.01)$ yang berarti hipotesis dalam penelitiannya diterima yaitu pelatihan strategi peningkatan efikasi diri para guru mampu meningkatkan efikasi diri kemampuan matematika siswa sekolah dasar.

Efikasi diri memegang peranan penting dalam kehidupan sehari-hari, di mana seseorang dapat menggunakan potensi dan kemampuannya secara optimal apabila efikasi diri atau keyakinan dirinya mendukung (Bandura, 1997). Dijelaskan lebih lanjut bahwa efikasi diri merupakan suatu keyakinan diri seseorang akan kemampuan-kemampuannya untuk mengatur dan melaksanakan serangkaian tindakan yang diperlukan untuk menghasilkan suatu hal. Keyakinan akan seluruh kemampuan ini meliputi kepercayaan diri, kemampuan menyesuaikan diri, kapasitas kognitif, kecerdasan dan kapasitas bertindak pada situasi yang penuh tekanan. Efikasi diri merupakan salah satu faktor personal yang menjadi 
perantara atau mediator dalam interaksi antara faktor perilaku dan faktor lingkungan. Efikasi diri dapat menjadi penentu keberhasilan performansi dan pelaksanaan pekerjaan. Senada dengan Monks, Knoers, dan Haditono (2003), bahwa efikasi juga sangat mempengaruhi pola pikir, reaksi emosional dalam membuat keputusan.

Bandura (1997) menyatakan bahwa untuk meningkatkan efikasi diri seseorang dapat ditingkatkan dengan memberikan pelatihan efikasi diri yang terdiri dari pemberian vicarious exerience, verbal persuation, physiological state dan mastery experience. Pertama yaitu vicarious experience, cara yang paling efektif untuk menciptakan dan menumbuhkan efikasi diri dengan diri dengan cara mengamati keberhasilan orang lain (vicarius experience). Bandura (1997) menyatakan bahwa individu yang melihat keberhasilan orang lain dalam melakukan suatu aktivitas yang sama dan memiliki kemampuan yang sebanding, maka dapat meningkatkan efikasi dirinya. Dengan mengamati keberhasilan orang lain dalam melakukan tugas atau menangani sebuah situasi dapat membantu seseorang untuk melakukan tugas yang sama dengan cara mengimitasi atau mencontohnya. Individu yang awalnya memiliki efikasi diri yang rendah akan berusaha untuk dapat mencapai keberhasilan seperti yang diperoleh orang lain. Jika individu berhasil melakukan tugasnya, maka individu akan berfikir bahwa dirinya akan berhasil dalam melakukan tugas tersebut. Mengamati orang lain yang sukses mengerjakan hal yang sama akan meningkatkan keyakinan bahwa individu dapat menguasai aktivitas/tugas yang sama. Hal ini didukung oleh hasil penelitian dari Martino et al. (2005) yang meyebutkan bahwa pengaruh tayangan adegan seks di televisi terhadap perilaku seksual remaja menunjukkan bawa model di televisi tersebut mempengaruhi perilaku remaja untuk melakukan hubungan seks pranikah.

Berdasarkan hasil observasi ketika pelatihan berlangsung dan hasil evaluasi yang dilakukan terdapat adanya perubahan efikasi diri pada orang tua terhadap kemampuan berwirausaha anak Down syndrome. Hal ini ditunjukkan dengan masih ragu-ragunya subjek penelitian akan kemampuan berwirausaha anak Down syndrome seperti tidak yakinnya subjek bahwa anak Down syndrome mampu membeli barang dagangan, menjual barang dagangan, dan tidak yakin mampu menawarkan barang dagangannya. Namun, setelah ditunjukkan video tentang anak Down syndrome yang mampu menejalankan usahanya sendiri dengan didampingi orangtuanya, subjek mulai terbuka pandangan dan pemahamannya disertai rasa haru bahwa ternyata anak Down syndrome apabila didampingi dan diajarkan untuk berwirausaha akan mampu melakukannya walaupun tidak sesempurna orang-orang normal lainnya. Subjek menyatakan bahwa, ternyata anak Dwon syndrome mampu untuk mengelola usahanya sendiri dengan didampingi orangtuanya. Hal ini diperkuat 
dengan penjelasan-penjelasan yang diberikan oleh narasumber mengani cerita keberhasilannya dalam mendidik dan mengajarkan anaknya yang juga Down syndrome dalam berwirausaha. Selain itu, narasumber juga membagikan tips-tips bagaimana memulai usaha dan bagaimana mengajarkan serta mendampingi anak Down syndrome dalam melakukan wirausaha. Subjek mulai yakin bahwa anak-anaknya juga mampu berwirausaha sama seperti video yang barusan ditonton dan juga cerita dari narasumber. Beberapa subjek menyatakan bahwa anaknya telah mampu membeli barang di toko langganan, dan ada pula yang menyatakan bahwa anaknya terkadang turut membantu menawarkan dan melayani pembeli di toko milik keluarga meskipun dengan instruksi yang masih sederhana seperti mengetahui beberapa harga barang dagangan. Keyakinan ini terbentuk dari penilaian yang positif subjek terhadap video dan juga cerita keberhasilan mendidik anak Down syndrome dalam berwirausaha oleh narasumber, di mana hasilnya adalah setuju bahwa anak Down syndrome mampu untuk berwirausaha (Baron \& Byrne, 2005). Penilaian yang positif ini terhadap keberhasilan orang lain dalam melakukan suatu aktivitas dapat meningkatkan efikasi diri pada individu (Bandura, 1997).

Cara kedua untuk meningkakan efikasi diri adalah dengan cara memberikan pengalaman keberhasilan langsung (mastery experience) (Bandura, 1997). Pengalaman keberhasilan tersebut akan mempengaruhi perspektif kemampuannya. Hal ini akan menuntun kepada efikasi diri yang tinggi. Sebaliknya kegagalan akan melemahkan atau menurunkan efikasi diri. Terbentukknya efikasi diri, individu harus pernah mengalami tantangan yang berat, sehingga individu dapat menyelesaikannya dengan kegigihan dan kerja keras. Perkembangan efikasi diri di samping ditentukan oleh keberhasilan dan kegagalan yang telah dilakukan juga ditentukan oleh kesalahan dalam menilai diri. Apabila dalam kehidupan sehari-hari yang selalu diingat adalah penampilan yang kurang baik, maka efikasi diri akan rendah. Sebaliknya, apabila kegagalan yang dialami dimaknai sebagai suatu yang perlu ditingkatkan dan diperbaiki, maka efikasi diri akan meningkat. Pengalaman-pengalaman tersebut menjadi penentu yang penting terhadap efikasi diri seseorang melalui representasi kognitif. Hal ini meliputi ingatan terhadap frekuensi keberhasialn dan kegagalan, pola temporernya serta dalam situasi bagaimaan terjadinya keberhasilan dan kegagalan. Uzuntriyaki (2008), menyatakan bahwa di antara empat sumber yang mempengaruhi perkembangan efikasi diri, pengalaman pribadi (mastery experience) lah yang paling berperan dalam meningkatkan efikasi diri.

Dalam penelitian ini, subjek diberikan kesempatan untuk mendapatkan pengalaman secara langsung mempraktekkan kegiatan berwirausaha dengan anak Down syndrome. 
Dalam hal ini subjek (orangtua) akan diberikan dana stimulasi dan diminta melakukan percobaan memberikan tugas kepada anaknya untuk berwirausaha secara sederhana (berjualan alat tulis, makanan ringan, dll). Pada awalnya para orangtua agak ragu apakah anaknya benar-benar mampu melakukan kegiatan jual beli. Namun setelah diberikan paparan video dan juga kisah sukses dalam mendidik dan mendampingi anak Down syndrome dalam berwirausaha, maka para orangtua menjadi lebih yakin dan semangat untuk mempraktekkannya dengan anak-anaknya. Setelah seminggu waktu yang diberikan untuk mempraktekkan kegiatan berwirausahanya. Para orangtua dikumpulkan kembali untuk membagikan pengalaman masing-masing selama seminggu praktek berwirausaha dengan anak Down syndrome. Para orangtua menceritakan bahwa anak-anaknya mampu dalam mempraktekkan kegiatan berwirausahanya, seperti anak mampu menjajakan/ menawarkan barang dagangannya kepada para pembelinya, meskipun dengan cara yang sangat sederhana (misal: jualan peyek, anak menawarkan dengan mengatakan "eyek eyek"), selain itu anak juga dapat menunjukan harga barang dagangan (dengan menunjukkan telunjuknya yang berarti harganya serubu rupiah). Dalam hal ini memang pembelajaran dan pembiasaan yang diberikan kepada anak-anak haruslah yang sederhana dan diulang-ulang secara terus menerus, karena anak Down syndrome kemampuan yang rendah dan keterlambatan dalam kemampuan mentalnya (Kathlyn, 2001). Sehingga harus diberikan secara berulang dengan instruksi yang sederhana. Dengan melihat keberhasilan anak-anak Down syndrome dalam berwirausaha (berjualan secara sederhana), maka para orangtua semakin yakin bahwa anakanaknya akan mampu untuk berwirausaha apabila didampingi dan diajarkan terus untuk berwirausaha. Hal ini ditunjukkan dengan respon orangtua yang menyatakan bahwa "saya yakin bahwa anak saya mampu untuk berjualan dan melakukan sesuatu”. Selain itu, juga ditunjukkan bahwa orangtua semakin yakin bahwa anaknya mampu mempersiapakan sampai menjual barang dagangannya sendiri, walaupun masih tetap harus diawasi oleh orangtua pada awalnya.

Cara ketiga untuk meningkatkan efikasi diri adalah dengan cara menjaga kondisi emosional dan tubuhnya (Bandura, 1997). Suasana hati, emosi, reaksi fisik dan tingkat stres dapat mempengaruhi bagaimana seseorang menyakini tentang kemampuannya. Jika seseorang merasa sangat cemas, maka akan muncul keraguan dan cenderung diartikan sebagai suatu kegagalan, hal inilah yang akan menurunkan efikasi diri. Sebaliknya, jika seseorang merasa percaya diri dan tidak cemas, maka seseorang akan mengalami rasa ketertarikan yang sangat tinggi yang pada akhirnya akan meningkatkan efikasi diri. Senada dengan penelitian McDougall dan Kang (2003) yang menyebutkan bahwa efikasi diri 
berkorelasi negatif dengan kecemasan. Artinya apabila kecemasannya tinggi maka efikasi diri tersebut akan mengalami penurunan, namun sebaliknya apabila kecemasannya rendah dalam melakukan suatu hal, maka efikasi dirinya akan semakin meningkat atau tinggi.

Pada awal pertemuan dalam pelatihan, para orangtua terlihat tegang dan kurang nyaman dengan dikumpulkannya di dalam ruangan yang sama. Guna mencairkan suasana trainer melakukan perkenalan baik diri trainer sendiri dan juga masing-masing peserta, setelah itu trainer memberikan ice breaking yang berfungsi sebagai pemecah kebekuan dan membuat para orangtua menjadi lebih nyaman. Selain itu, tugas yang diberikan dalam praktek berwirausaha dengan anak Down syndrome juga merupakan tugas yang menyenangkan, yaitu berjualan dengan tingkat yang sangat sederhana, yaitu membeli barang dagangan, mempersiapankan, menawarkan, menjual dan membereskan barang dagangannya kembali. Sebelumnya, para orangtua juga telah mendapatkan tips-tips dan cara-cara bagaimana memulai mengajaran dan mendampingi anak dalam berjualan. Sehingga kondisi ini menciptakan suasana yang nyaman dan tidak tegang. Kondisi nyaman inilah yang dapat meningkatkan keercayaan diri dan tidak cemas pada masing-masing orangtua, sehingga ketertarikan terhadap materi yang akan diberikan semakin tinggi. Hal inilah yang membuat efikasi diri orangtua menjadi meningkat (Bandura, 1997).

Cara keempat untuk meningkatkan efikasi diri adalah dengan persuasi verbal (verbal persuation), yaitu dengan cara memberikan saran, nasehat, bimbingan sehingga dapat meningkatkan keyakinan bahwa kemampuan-kemampuan yang dimiliki dapat membantu dalam mencapai apa yang diinginkan (Bandura, 1997). Dijelaskan lebih lanjut bahwa orang yang berpengaruh apabila menyampikan secara verbal pada seseorang mengenai kemampuannya dapat meyakinkan bahwa dirinya akan mampu dalam melakukan tugasnya. Verbal persuasi adalah proses merubah sikap seseorang yang awalnya tidak yakin menjadi lebih yakin terhadap kemampuannya dalam melakukan sesuatu dengan menggunakan katakata (Baron \& Byrne, 2005). Ketika ada orang lain mendorong dan meyakinkan bahwa seseorang mampu melakukan tugasnya, maka orang tersebut cenderung yakin dirinya mampu melakukan tugas tersebut. umpan balik yang konstruktif penting dalam memelihara efikasi diri yang tinggi dan melawan keraguan diri (Bandura, 1997). Pesan persuasif ini dipandang sebagai usaha yang disadari untuk mengubah pola pikir, rasa dan tindakan dengan memanipulasi motif-motif ke arah yang telah ditetapkan atau yang diinginkan (Ritonga, 2005). Makna memanipulasi di sini lebih diartikan sebagai penggunaan fakta-fakta yang berkaitan dengan motif-motif seseorang, sehingga seseorang tersebut tergerak untuk mengikuti maksud pesan yang disampaikan kepadanya. Semakin percaya orang kepada 
kemampuan pemberi informasi maka akan semakin kuat keyakinan untuk dapat merubah efikasi diri (Bandura, 1997). Persuasi verbal akan berhasil dengan baik apabila orang yang memberikan informasi mampu menjelaskan kelemahan dan kelebihan orang yang bersangkutan, serta mengetahui pengetahuan atau keterampilan yang dapat mengaktualisasikan potensi individu tersebut.

Pada tahap kedua, para orangtua dikumpulkan kembali guna menceritakan dan berbagi pengalaman selama seminggu melakukan praktek wirausaha dengan anak Down syndrome. Para orangtua bercerita satu persatu dengan semangatnya. Hal ini terlihat dari ekspresi dan gerak tubuhnya, bahkan sebelum acara dibuka, para orangtua sudah saling berebut untuk mendahului menceritakan pengalamnnya dalam berwirausaha. Setelah acara dibuka, pemandu memberikan kesempatan satu persatu para orangtua untuk menceritakan pengalamannya. Selama proses bercerita pemandu mendengarkan dengan seksama dengan sesekali memberikan probbing atau penekanan terkait dengan apa yang diceritakan. Pemandu juga memberikan kata-kata persuasi, seperti "ternyata putranya bisa menawarkan barang dagangan ya bu" "wah putanya hebat ya bu” dan lain-lain. Hal ini membuat orangtua semakin bersemangat dan percaya diri dalam menceritakan pengalamannya tersebut. Selain itu, orangtua yang lain juga memberikan kata-kata persuasi kepada orangtua yang sedang bercerita, seperti "Hebat memang mamanya Atun..." "Saya sempat meniru cara mama Atun dalam mengajarkan Atun menawarkan barang...” dan lain-lain. Dengan persuasi verbal yang diberikan ini keyakinan diri/ efikasi diri terhadap kemampuan berwirausaha anak Down syndrome pada orangtua semakin meningkat. Hal ini juga ditunjukkan dengan semakin yakinnya para orangtua bahwa anaknya mampu menjual barang dagangannya, mampu menyajikan barang dagangan bahkan orangtua juga yakin bahwa anaknya mampu berinteraksi dengan para pelangan. Walaupun hal tersebut harus didampingi terlebih dahulu oleh orangtua. Selain itu, para orangtua juga menyatakan bahwa akan tetap melanjutkan kegiatan wirausaha dengan anak-anaknya. Selain sebagai tambahan penghasilan, hal ini juga dimaknai sebagai salah satu cara untuk mengajarkan dan membiasakan anak-anak Down syndrome untuk mendapatkan penghasilannya sendiri.

Berdasarkan uraian di atas dapat diketahui bahwa pelatihan efikasi diri dapat dijadikan sebagai media yang efektif untuk meningkatkan efikasi diri terhadap kemampuan berwirausaha anak Down syndrome pada orangtua. Melalui pelatihan efikasi diri, efikasi diri yang rendah terhadap kemampuan berwirausaha anak Down syndrome pada orangtua dapat ditingkatkan sehingga berada pada kategori sedang. 
Berdasarkan uraian di atas dapat diketahui bahwa pelatihan efikasi diri dapat dijadikan sebagai media yang efektif untuk meningkatkan efikasi diri terhadap kemampuan berwirausaha anak Down syndrome pada orangtua. Melalui pelatihan efikasi diri, efikasi diri yang rendah terhadap kemampuan berwirausaha anak Down syndrome pada orangtua dapat ditingkatkan sehingga berada pada kategori sedang.

\section{KESIMPULAN}

Berdasarkan analisis data tersebut dapat disimpulkan bahwa hipotesis dalam penelitian ini diterima. Hipotesis yang menyatakan ada perbedaan yang signifikan antara tingkat efikasi diri terhadap kemampuan kewirausahaan anak Down syndrome sebelum (pretest) dan sesudah (posttest) diberikan pelatihan efikasi diri diterima. Hasil analisis menunjukkan bahwa ada perbedaan rata-rata skor tingkat efikasi diri terhadap kemampuan kewirausahaan anak Down syndrome sebelum (pretest) dan sesudah (posttest) diberikan pelatihan efikasi diri z -2.207, $\mathrm{p}=0.027$ ( $\mathrm{p}<0.05$ ). Skor efikasi diri subjek sebelum diberikan pelatihan efikasi diri lebih rendah (Mean $=41,5)$ dibandingkan dengan skor efikasi diri subjek setelah diberikan pelatihan efikasi diri $($ Mean $=54,67)$.

\section{SARAN}

\section{Bagi Subjek (orangtua)}

Subjek hendaknya bersedia melajutkan secara mandiri untuk mencoba wirausaha secara serderhana dengannya dan mencari informasi tentang bukti-bukti keberhasilan anak Down syndrome dalam berwirausaha agar efikasi diri dapat meningkat

\section{Bagi penelitian selanjutnya}

Bagi peneliti lain yang tertarik meneliti hal yang sama, disarankan Peneliti selanjutnya sebaiknya menambah waktu penelitian lebih lama lagi agar perubahan perilaku lebih terlihat. Selain itu, peneliti selanjutnya juga perlu juga mempertimbangkan jenis wirausaha yang cocok bagi anak Down syndrome.

\section{Pihak terkait (psikolog, mahasiswa mapro)}

Dapat menggunakan pelatihan efikasi diri untuk meningkatkan efikasi diri orang tua terhadap kemampuan kewirausahaan anak Down syndrome

\section{DAFTAR PUSTAKA}

Ancok. (2002). Outbond management training. Yogyakarta: UII Perss.

Azwar, S. (1999). Metode penelitian. Yogyakarta : Pustaka Pelajar 
Bandura, A. (1997). Self-efficacy: The excercise of control. New York: Freeman.

Bandura, A. (2009). Self-efficacy in changing societies. New York: Cambridge University Press.

Baron, R.A., \& Byrne, D. (2004). Psikologi sosial. Jakarta: Erlangga.

Bernstein, D. A., Nietzel, M. T., \& Milich, R. S. (1998). Introduction to clinical psychology (5th edition). Englewood Cliffs, NJ: Prentice-Hall, Inc.

Baron, R.A., \& Byrne, D. (2004). Psikologi Sosial. Jakarta: Erlangga.

Buckley, Sue. (2000). Down Syndrome Issues and Information: Overview Living With Down Syndrome. Hamprhire: The Down Syndrome Educational Trust.

Buckley, S. \& Bird, G. (2001). Memory development for individuals with Down syndrome. Portsmouth, UK: The Down Syndrome Educational Trust.

Helmystianti, VE. (2017). Pengaruh peningatan efikasi diri pada guru untuk meningkatkan efikasi diri kemampuan matematika siswa sekolah dasar. Skripsi. Yogyakarta: Fakultas Psikologi, Universitas Mercu Buana Yogyakarta.

Kathlyn, Reed L. (2001). Quick Reference to Occuptional Therapy. Texas: Housten Center.

Martino, SC., Collins, RL., Kanouse, DE., Elliot, M., \& Berry, SH. (2005). Social cognitive processes mediating the relationship between exposure to television's sexual content and adolescents' sexual behavior. Journal of personality and Social Psychology, 89(6), 914-924.

McDougall, GJ., \& Kang, J. (2003). Memory self-efficacy and memory performance in older males. International J ournal pf M en's H ealth, 2(2), 131-147.

Monks, F.J., Knoers, A.M.P., \& Haditono, S.R. (2004). Psikologi perkembangan: Pengantar dalam berbagai bagiannya. Yogyakarta: Gadjah Mada University Press.

Ritonga, M. J. (2005). Tipologi pesan persuasif. Jakarta: PT. Indeks.

Sadock, J. B. Kaplan, I. H., \& Grebb, A. J. 1997. Sinopsis psikiatri ilmu pengetahuan prilaku psikiatri klinis. (Edisi ke-7. jilid 2). Jakarta: Bina Rupa Aksara.

Trihendradi, C. (2009). Step by Step SPSS 16 : Analisis Data Statistik. Yogyakarta : Penerbit Andi Offset

Uzuntiryaki, E. (2008). Exploring the sources of turkish pre-srvice chemistry teachers' chemistry self-efficacy beliefs. Australian Journal of Teacher Education, 33(6), 1228. 